\section{Commentary: Radical solutions for radical problems: A tale of success and caution}

\author{
Siva Raja, MD, PhD
}

In the treatment of thoracic malignancies, between the realms of resectable and unresectable, a small number of patients exist who can potentially reside in either realm based on patient characteristics and availability of cumulative surgical expertise. In this case report, Galvaing and colleagues ${ }^{1}$ describe a challenging case of a right upper lobe tumor that required a bronchial sleeve, pulmonary arterioplasty, and superior vena cava (SVC) reconstruction. Ultimately, the surgical team was able to achieve an R0 resection resulting in long-term, disease-free survival of the patient. Along their perilous journey, they encountered numerous obstacles. They encountered positive margins requiring re-resection, SVC syndrome from the patch venoplasty that necessitated reconstruction, and vocal cord paralysis that complicated postoperative recovery.

By any measure, the case being discussed represents a very challenging surgical problem that required appropriate planning where these pitfalls needed to be anticipated and their rescues pre-planned. In this case, the patient seemed to be a marginal candidate for a pneumonectomy, which would have been a reasonable therapy for this problem in many patients. Perhaps radiation is a reasonable adjunct if the second bronchial margin had been positive for cancer. Lastly, having a surgeon with the expertise to reconstruct the SVC available on backup was a key component in the success that was achieved that day.

\footnotetext{
From the Department of Thoracic and Cardiovascular Surgery, Heart and Vascular Institute, Cleveland Clinic, Cleveland, Ohio.

Disclosures: The author reported no conflicts of interest.

The Journal policy requires editors and reviewers to disclose conflicts of interest and to decline handling or reviewing manuscripts for which they may have a conflict of interest. The editors and reviewers of this article have no conflicts of interest.

Received for publication Aug 12, 2020 ; revisions received Aug 12, 2020; accepted for publication Aug 14, 2020; available ahead of print Aug 15, 2020.

Address for reprints: Siva Raja, MD, PhD, Cleveland Clinic Foundation, 9500 Euclid Ave, J4-1, Cleveland, OH 44195 (E-mail: rajas@ccf.org).

JTCVS Techniques 2020;4:326-7

2666-2507

Copyright $(2020$ The Authors. Published by Elsevier Inc. on behalf of The American Association for Thoracic Surgery. This is an open access article under the CC BY-NCND license (http://creativecommons.org/licenses/by-nc-nd/4.0/).

https://doi.org/10.1016/j.xjtc.2020.08.038
}

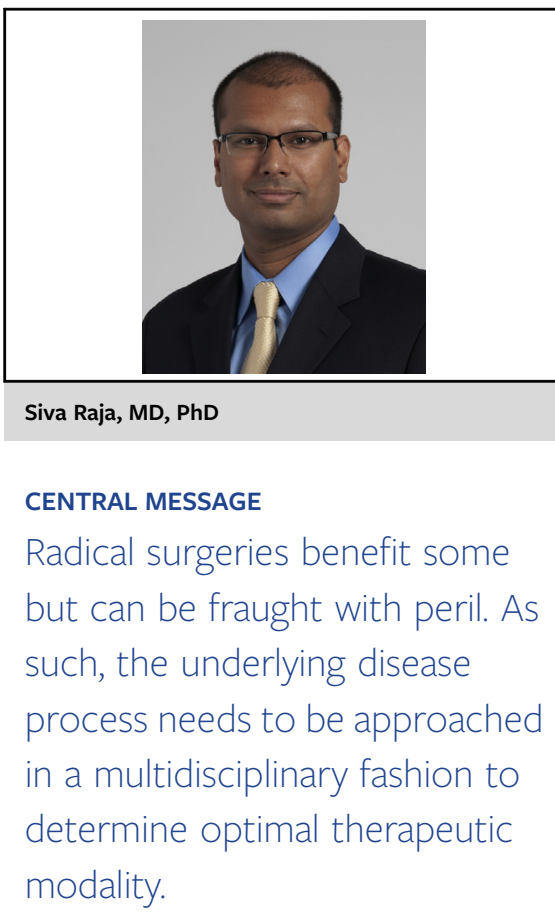

This tale of success is also a tale of caution. The authors discuss a few other publications that report on patients who have successfully undergone this type of complex reconstruction. The combined number of cases is in single digits. This leaves this author wondering about the many patients who underwent this type of surgery who did not have a favorable outcome. We, as surgeons, are not always as eager to report our failures as we are to report our successes. However, the most important tenet that an oncologic surgeon needs to adhere to is that biology is king! The overall survival for stage IIIB (T4 N2) lung cancer is $26 \% .^{2}$ In longer-term surgical series from experienced centers-in a highly selected patient population-SVC resection has a 5 -year survival between $38 \%$ and $47 \% .^{3,4}$ These survival estimates are for garden variety non-small cell lung cancer. In this case, the patient had pleomorphic carcinoma with nodal metastasis. This has a particularly worse prognosis with a tendency to recur early, although this patient did well. ${ }^{5}$ As such, it is important to assess the oncologic value and survival benefit of surgery over definitive medical therapy when considering complex resections that carry significant morbidity and mortality. Without thoughtful consideration, not every tale will have a happy ending.

\section{References}

1. Galvaing G, Sassi S, Dagenais F, Conti M. Triple-sleeve lobectomy for non-small cell lung cancer: lessons from a case. J Thorac Cardiovasc Surg Tech. 2020;4: $323-5$. 
2. Goldstraw P, Chansky K, Crowley J, Rami-Porta R, Asamura H, Eberhardt WE, et al. The IASLC Lung Cancer Staging Project: proposals for revision of the TNM stage groupings in the forthcoming (Eighth) edition of the TNM classification for lung cancer. J Thorac Oncol. 2016;11:39-51.

3. Dartevelle PG, Mitilian D, Fadel E. Extended surgery for T4 lung cancer: a 30 years' experience. Gen Thorac Cardiovasc Surg. 2017;65:321-8.
4. Yildizeli B, Dartevelle PG, Fadel E, Mussot S, Chapelier A. Results of primary surgery with T4 non-small cell lung cancer during a 25-year period in a single center: the benefit is worth the risk. Ann Thorac Surg. 2008;86: 1065-75.

5. Zhang DM, Wei JG. Metastatic pleomorphic adenoma of lung: report of a case [article in Chinese]. Zhonghua Bing Li Xue Za Zhi. 2017;46:59-60. 